\title{
Malignant Epithelial Tumor in a Patient with Recurrent Axillary Abscess
}

\author{
Tekrarlayan Aksillar Apse ile Gelen Hastada Malign Epitelyal Tümör
}

\author{
Mehmet PATMANO \\ (i) 0000-0002-1755-614X \\ Durmuş Ali ÇETİN ${ }^{1}$ \\ (D) 0000-0003-3012-6774 \\ Tufan GÜMÜŞ ${ }^{1}$ \\ (D) 0000-0003-1861-8282 \\ Özlem KARA ${ }^{2}$ \\ (10) 0000-0001-6971-1298
}

\begin{abstract}
${ }^{1}$ Şanlıurfa Education and Research Hospital General Surgery Clinic, Şanlıurfa, Turkey
\end{abstract}

${ }^{2}$ Şanlıurfa Education and Research Hospital Pathology Clinic, Şanlıurfa, Turkey

\section{Corresponding Author Sorumlu Yazar \\ Mehmet PATMANO \\ mpatmano@yahoo.com}

Received / Gelis Tarihi : 27.04.2020

Accepted / Kabul Tarihi : 10.07.2020

Available Online /

Çevrimiçi Yayın Tarihi : 25.08.2020

\begin{abstract}
Skin infections are among the common diseases encountered in general surgery, dermatology and pediatrics outpatient clinics. Skin abscess occurs as a result of pus accumulation in the dermis or subcutaneous tissue; it is composed of swollen, red, tender, fluctuating mass and often accompanied by cellulite around them. The treatment is primarily antibiotic therapy according to the abscesses culture result after drainage with local anesthesia. Some of diseases such as diabetes, immunosuppressive conditions and cancer should be considered in adults, especially in recurrent abscesses. Skin metastasis in primary malignancies is very rare. Lung cancer is the most common one with skin metastasis. In this case report, we wanted to emphasize that the skin metastasis of primary malignancy should be kept in mind in cases with recurrent abscess which is resistant to treatment.

Keywords: Abscess; tumor; skin metastasis.
\end{abstract}

ÖZ

Deri enfeksiyonları genel cerrahi, dermatoloji ve pediatri polikliniklerinde sık karşılaşılan hastalıklar arasında yer almaktadır. Deri apsesi, dermiste veya subkutan dokuda püy birikmesi sonucunda meydana gelir; şiş, kızarık, hassas, fluktuasyon veren ve çoğunlukla çevresinde selülitin eşlik ettiği bir görünüme sahiptir. Tedavi lokal anestezi altında drenaj sonrasında apse kültürü sonucuna göre öncelikle antibiyotik tedavisidir. Erişkinlerde özellikle tekrarlayan apselerde diyabet, bağışıklık sistemini baskılayan durumlar ve kanser gibi bazı hastalıklar göz önünde bulundurulmalıdır. Primer malignitelerde cilt metastazı gelişimi çok nadirdir. Cilt metastazı nedeni olarak akciğer kanseri ilk sırada yer alır. Bu olgu sunumunda, tedaviye dirençli tekrarlayan apse olgularında primer malignitenin cilt metastazının akılda tutulması gerektiğini vurgulamak istedik.

Anahtar kelimeler: Apse; tümör; cilt metastazı.

\section{INTRODUCTION}

Skin is the largest organ and one of the important defense mechanisms for our body. The epidermis consists of dermis and subcutaneous tissue. Gram positive bacteria are the most common microorganisms in the skin flora. Predisposing factors for skin and soft tissue infections are; trauma, immune deficiency, venous and lymphatic drainage problems, local inflammatory disorder, foreign body, vascular insufficiency, obesity, poor hygiene (1).

Skin infections are common diseases in general surgery, dermatology and pediatrics outpatient clinics. Skin abscesses occur as a result of pus accumulation in the dermis or subcutaneous tissue. It has four cardinal signs of inflammation; redness, heat, swelling, and pain. The treatment is primarily antibiotic therapy according to the abscesses culture result after drainage (2,3). If recurrent abscesses occur in early childhood, patients should be examined for neutrophil disturbances. Some of systematic diseases 
such as diabetes, immunosuppressive conditions and cancer should be considered in adults, especially in recurrent abscesses. Skin metastasis in primary malignancies is very rare. Lung cancer is the most common one with skin metastasis. Skin metastasis could be the first symptom of lung cancer (4). Pathological determination of skin metastasis is very important, because the asymptomatic patients could be diagnosed earlier $(5,6)$. In this case report, we wanted to emphasize that the skin metastasis of primary malignancy should be kept in mind in cases of subcutaneous recurrent abscesses.

\section{CASE REPORT}

A 52-year-old woman presented to our hospital with complaints of pain, swelling and redness under the left axilla. The patient had diabetes mellitus as systematic disease and under the control with oral antidiabetics. In physical examination, there was swelling and redness in the left axilla. Breast examination was normal. Breast ultrasonography and mammography were performed to the patient. According to the ultrasonography; 50x34 mm, irregular bounded, dense, liquid locus (abscess?) was observed in the left axilla. No pathological findings were found in the breast tissue. Mammography revealed vascular wall calcifications in bilateral breast parenchyma. Laboratory results of the patient was as follows; WBC:12000 $/ \mu \mathrm{L}, \mathrm{Hgb}: 12.4 \mathrm{~g} / \mathrm{dL}$, Plt:128000 $/ \mu \mathrm{L}$ and CRP: $145.5 \mathrm{mg} / \mathrm{L}$. The patient underwent abscess drainage with local anesthesia (jetosel ${ }^{\mathrm{R}}$, lidocaine and epinephrine, Osel) and the sample for abscess culture was taken. There was no growth in the culture of the patient. Ampicillinsulbactam $1000 \mathrm{mg}$ oral treatment for 7 days was given. The patient was followed with daily dressing. After 3 weeks from the first drainage, the patient's abscess was recurred in the same localization. After the drainage under local anesthesia, no growth in the culture was detected again. Ampicillin-sulbactam (1000 mg, 2x1) and metronidazole $(3 \times 500 \mathrm{mg})$ were ordered to the patient. The patient was followed with daily dressing and cavity washing procedures. During the follow-up, a fistulated abscess was detected at the same location which forms fistula to skin at different locations 1.5 months later (Figure 1). The patient underwent an abscess drainage again. Skin biopsy was performed to the patient due to granulomatous diseases and suspicion of malignancy. The patient's biopsy revealed as malignant epithelial tumor, primarily squamous cell carcinoma. Tumor cells have abundant eosinophilic cytoplasm and a large vesicular nucleus. There is focal keratinization, keratin pearls and moderate nuclear atypia. Squamous differentiation in these cytologically malignant cells, is manifest by squamous pearl and keratinization (Figure 2). The patient was examined with thoracic and abdominal computed tomography (CT). In thorax CT slight irregular bordered densities were observed in the upper and lower lobes of both lungs. The patient was referred to the medical oncology clinic in terms of primary pulmonary malignancy and skin metastasis.

\section{DISCUSSION}

In case of recurrence of subcutaneous abscesses which are among the reasons of frequent application to our clinic, systemic diseases and immunodeficiency conditions such as cancer should be kept in mind. Skin metastasis in primary malignancies is very rare. Lung cancer is the most common one with skin metastasis. As in our patient, skin metastasis may be the first finding in the patients (7). The pathological definition of skin metastasis in patients is important in two aspects. It enables us to reach the diagnosis in patients who are asymptomatic, and it is important in the follow-up of patients with cancer diagnosis in terms of treatment failure $(5,6)$.

Skin metastasis as the first symptom is seen in $20 \%$ of cancer patients (5). First of all, skin metastasis in lung and kidney cancers could be seen as the first symptom (8). Skin metastasis have clinical different meanings. It could be the first symptom of a silent cancer. Brownstein and Helwig report that this is especially seen in lung and kidney cancers (9). Therefore in patients with a history of new developing skin lesions, especially in older patients, smokers and patients with a history of cancer in their families, histopathological diagnosis by taking a biopsy from the lesion is necessary to exclude the possibility of malignancy. Metastatic skin lesions are usually $1-3 \mathrm{~cm}$ in size and hard, painless, mobile lesions with normal skin color (7). Rarely, fruncle-like nodules, erosions, and ulcerated granuloma-like papules may occur (10-12). In

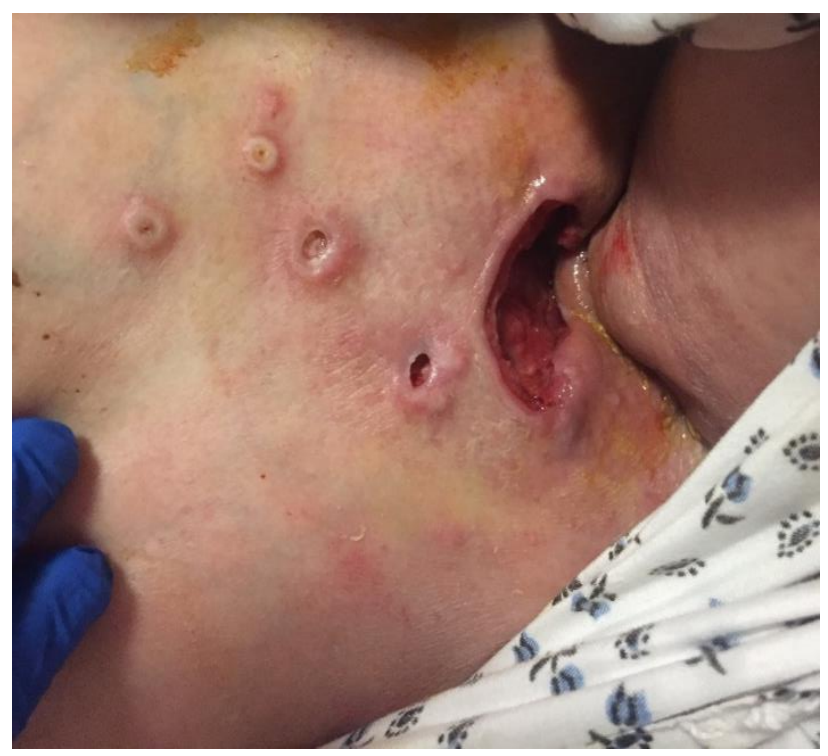

Figure 1. Fistulated abscess to skin

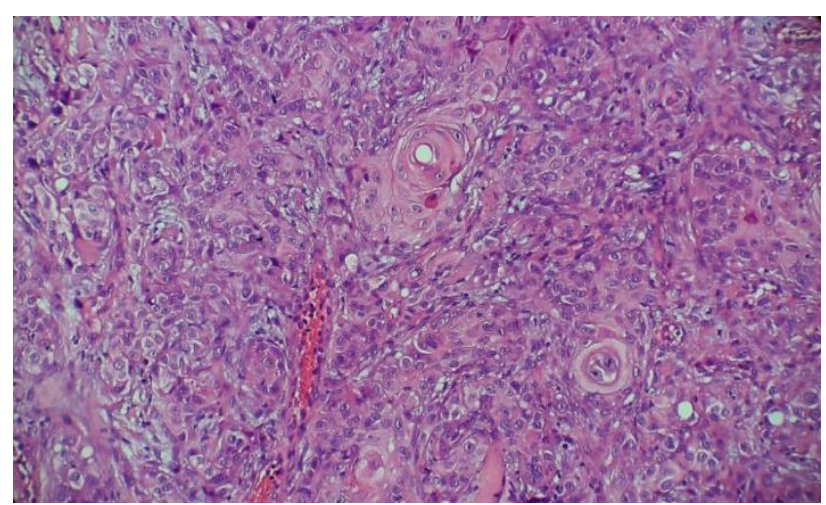

Figure 2. Histopathological image: focal keratinization, keratin pearls and moderate nuclear atypia (HEx100) 
our case, fistulization in the form of papules was observed during the follow-up. Skin lesions are classified according to their appearance as follows; nodular, inflammatory and sclerodermoid metastatic lesions (5). Nodular type is the most common one, usually shows hematogenous spread and seems multiple (13-15). Skin metastasis could be seen in the region close to primary tumor $(4,5,11)$. The most common site is the anterior chest wall $(5,9,11,16)$. In our case, abscess extending from the anterior axillary line to the chest wall was detected.

In conclusion, malignancies should be kept in the mind in cases with recurrent abscess which is resistant to treatment. It should be kept in the mind that skin lesions may be the first sign of a silent cancer.

We believe that histopathological diagnosis after skin biopsies will be useful especially in the middle age and older patients with smoking history in order to rule-out malignancies.

Acknowledgement: We especially thank the medical oncologist Elif ATAĞ for her support.

Conflict of Interest: No conflict of interest was declared by the authors.

Ethics Committee: The study was made according to Helsinki Declaration. Informed consent form was obtained from the patient.

Financial Disclosure: The authors declared that this study has received no financial support.

\section{REFERENCES}

1. Gül Ü. Common bacterial infections of the skin. Ankara Med J. 2016;16(1):98-114.

2. Hedrick J. Acute bacterial skin infections in pediatric medicine: current issues in presentation and treatment. Paediatr Drugs. 2003;5(Suppl 1):35-46.

3. Alter SJ, Vidwan NK, Sobande PO, Omoloja A, Bennett JS. Common childhood bacterial infections. Curr Probl Pediatr Adolesc Health Care. 2011;41(10):256-83.

4. Vila Justribó M, Casanova Seuma JM, Portero L, Egido R. Skin metastasis as the first manifestation of bronchogenic carcinoma. Arch Bronchopneumol. 1994;30(6):314-6.

5. Bhattarai B, Schmidt MF, Ghosh M, Sinha Ray A, Manhas S, Oke V, et al. Lung cancer with skin and breast metastasis: a case report and literature review. Case Rep Pulmonol. 2015;2015:136970.

6. Kurt B, Önal M, Erkan L, Samurkaşoğlu B. Akciğer kanserlerinde cilt metastazları. Solunum Hastalıkları. 1996;7:267-71.

7. Khaja M, Mundt D, Dudekula RA, Ashraf U, Mehershahi S, Niazi M, et al. Lung cancer presenting as skin metastasis of the back and hand: A case series and literature review. Case Rep Oncol. 2019;12(2),480-7.

8. Ichioka S, Yamada A. Ultrasonographic demonstration of a skin metastasis of adenocarsinoma. J Dermatol. 1994;21(9):690-2.

9. Pajaziti L, Hapçiu SR, Dobruna S, Hoxha N, Kurshumliu F, Pajaziti A. Skin metastases from lung cancer: a case report. BMC Res Notes. 2015;8(1):139.

10. Kanitakis J. Cutaneous metastases of internal cancers. Presse Med. 1993;22(13):631-6.

11. Coslett LM, Katlic MR. Lung cancer with skin metastasis. Chest. 1990;97(3):757-9.

12. Hidaka T, Ishii Y, Kitamura S. Clinical features of skin metastasis from lung cancer. Intern Med. 1996;35(6):459-62.

13. Kamiyoshihara M, Sakata K, Otani Y, Kawashima O, Takahashi T, Morishita Y. Solitary skin metastasis after lung cancer resection. Jpn J Thorac Cardiovasc Surg. 2002;50(8):343-6.

14. Dreiezen S, Dhingra HM, Chiuten DF,Umsawasdi T, Valdivieso M. Cutaneous and subcutaneous metastases of lung cancer. Clinical characteristics. Postgrad Med. 1986;80(8):111-6.

15. Lookingbill DP, Spangler N, Sexton FM. Skin involvement as the presenting sign of internal carcinoma. A retrospective study of 7316 cancer patients. J Am Acad Dermatol. 1990;22(1):19-26.

16. Terashima T, Kanazowa M. Lung cancer with skin metastasis. Chest. 1994;106(5):1448-50. 